\title{
IMPROVING THE ASSESSMENT OF THE ENVIRONMENTAL INDICATORS OF INVESTMENT PROJECTS BASED ON THE PUBLIC-PRIVATE PARTNERSHIP
}

\author{
Tatiana N. MALAKHOVA ${ }^{1}$, Konstantin P. KOLOTYRIN ${ }^{2}$, \\ Vladimir A. YAKUNIN ${ }^{3}$ \\ ${ }^{1-3}$ Saratov State Agrarian University named after N. I. Vavilov, Russia \\ shkatulka-girl@yandex.ru \\ kpk75@mail.ru \\ yakunin-w@yandex.ru
}

\begin{abstract}
Implementation of environmentally significant activities is often associated with the need to attract significant investment from different sources, both public and private. However, investors should be interested in the profitability of their investments and receiving definite guarantees. To this end, the article describes the method of estimating the cost-effectiveness of the investment attractiveness of the procedure, which is used today in domestic practice (Russia). Then it has been found how to change this procedure to allow estimating the high risk and uncertainty of projects. In particular, the authors suggest using an objective function, which they have developed for the evaluation of investment projects. The main goal of the objective function is not only to improve the production, but also to improve the ecological situation in the region.
\end{abstract}

Keywords: Environmental risk, greening, investment, investment risk, publicprivate partnership, social damage.

\section{INTRODUCTION}

Greening of modern economics occurs in difficult conditions of economic crisis and worsening of ecological situation. The presence of regional component in this process can help resolve the contradictions because exactly at the regional level the information about ecological and economic situation in this region is concentrated, and it allows making the most effective decisions in the field of economic and ecologic governance.

The industrial potential of the regional economy can be described as very high. A multi-industry system has formed in the region. The main industries are petroleum refining, chemical and construction industries. However, the growth of production and population density leads to the fact that human pressure on the environment increases, and the environmental situation in the area deteriorates.

The largest share among polluting industries is taken by businesses that are related to the production and distribution of electricity, gas and water, as well as chemical industry and pipeline transportation. These companies are the sources of 
emission of pollutants into the atmosphere. The emissions annually change in their structure and tend to increase on volume indicators.

The main source of information in this area of environmental pollution is statistical statements and reports of companies provided to the offices of the Regional Service for Supervision of Natural Resources.

For a comparative analysis, the methods of generalisation and critical review of the scientific experience were used. This experience was accumulated at the modern stage in the economic and environmental fields of science. Methods of economic analysis and synthesis in combination with a synergistic approach were also used.

Polluting enterprises are constantly investing in environmental protection and in fixed assets on the background of constant increase of negative impact on the environment. This has a significant impact on the environmental performance of their activities. At the same time, the major share $(70 \%)$ of investment is in companies' own funds. They borrow funds (loans) because the value of fixed assets is very high. These costs severely limit the company working capital.

As for industrial waste, the bulk of their proportion is in the enterprise processing and transport industries. About $88.1 \%$ of all waste generated in Saratov region in 2014 was the share of the processing industries.

At the same time, the major share of industrial waste is made by businesses of oil refining and transportation industries.

Thus, we can say that the investment in fixed assets, which companies make their own, are very small in order to provide the necessary environmental benefits.

Industrial production is growing rapidly. Therefore, the problem of negative impact on the environment should be in the interests of not only the producers, but also of the government (Guidelines for the Assessment of Investment Projects, 1999).

Table 1. The Dynamics of Investment in Fixed Assets of Conservation Importance for Saratov Region (unit is a million rubles) (Short Statistical Book. Saratov Region by Numbers - 2014, 2015)

\begin{tabular}{|l|c|c|c|c|c|c|}
\hline \multicolumn{1}{|c|}{ Index } & $\mathbf{2 0 1 0}$ & $\mathbf{2 0 1 1}$ & $\mathbf{2 0 1 2}$ & $\mathbf{2 0 1 3}$ & $\mathbf{2 0 1 4}$ & $\begin{array}{c}\text { Increase, } \\
\mathbf{\%}\end{array}$ \\
\hline $\begin{array}{l}\text { Investment in fixed assets of } \\
\text { conservation importance } \\
\text { including: }\end{array}$ & 634 & 386.4 & 469.3 & 177.8 & 564.2 & $\mathbf{8 9 \%}$ \\
\hline $\begin{array}{l}\text { protection and rational use of } \\
\text { water resources }\end{array}$ & 86.4 & 20 & 112.4 & 67 & 187.70 & $\mathbf{2 1 7} \%$ \\
\hline air protection & 73.9 & 87.7 & 10 & - & 175.90 & $\mathbf{2 3 8 \%}$ \\
\hline land reclamation & 463.5 & 278.6 & 346.9 & 110.1 & 93.30 & $\mathbf{2 0 \%}$ \\
\hline other & 10.2 & 0.1 & - & 0.7 & 107.30 & $\mathbf{1 0 5 2} \%$ \\
\hline
\end{tabular}


Despite the deterioration of the ecological situation in the region and increased attention on the part of environmental authorities, it does not work in the field of mechanisms to encourage the introduction of innovative technologies into production, which can significantly reduce the negative impact on the environment. This is due to the fact that there is no common policy in the rationalisation of nature based on the modern economic mechanisms that provide the efficiency of investment in the implementation of environmentally friendly and resource-saving technologies (Kolotyrin, 2015).

The modern approach to the ecologic governance of industrial activities should be based on combination of administrative and market mechanisms (Malakhova, 2014). The authors of this article consider that the use of Public Private Partnership instruments should have a positive impact on the regional economic development and on the state of the environment.

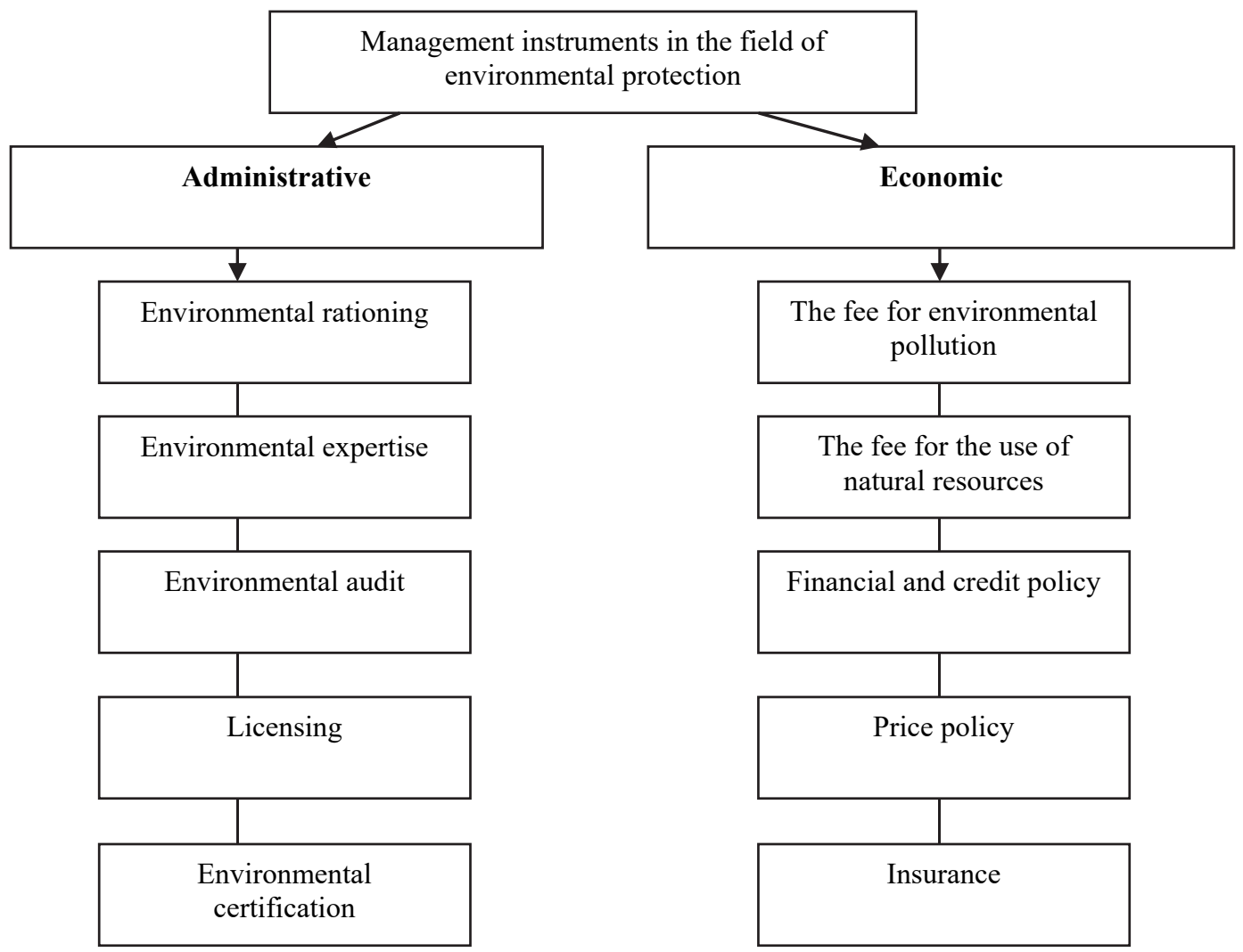

Fig. 1. The mechanisms of environmental management based on the direction of stimulating public-private partnerships.

Public-private partnership is based on the combination of state and public interests and should include all stages of the production process (planning, procurement, manufacturing, waste management). As it is known, the result of the investment project largely depends on how well and competently it is made. Project performance indicators are calculated based on the values of the input parameters (total investment). Design based on tools of public-private partnership 
gives investors the opportunity to see that the potential result is already in the planning stage. It becomes possible due to redistribution of the costs and risks associated with the project, among its participants.

This approach requires the creation and elaboration of legislative-legal and economic field, characterised by its own peculiarities. There are some problems in choosing priority directions of economics greening, as well as in the economic justification of investment projects.

Thus, for example, in the process of investment project formation it is necessary to choose a criteria (public or commercial efficiency) for its assessment that will most accurately reflect the ecological and economic essence of the proposed project and provide a clear understanding of the results of its implementation. When choosing the criteria, the main problem is the comparability of the different variants, risk management and the environmental component.

In international practice, for assessment and comparison of different investment projects such criteria are used as NPV, IRR, PI and others. However, for a more effective analysis of the represented variants, a systematic index that will reflect the influence of the environmental component on the economic effect is necessary. It is the use of this index that will allow highlighting and selecting among the represented projects those that have a direct environmental focus.

Within the framework of the research, two methods were used to compare the two approaches to evaluating the effectiveness of investment projects.

The first method of calculating the effectiveness of the investment project is based on methodical recommendations for the individual enterprise assessment (Guidelines for the Assessment of Investment Projects, 1999); the second method is developed by the authors on the basis of changes in tax and environmental legislation, in particular the Federal Law as of January 10, 2002 No. 7-FL "On Environmental Protection" with the latest changes.

Methodical recommendations are used (Guidelines for the Assessment of Investment Projects, 1999), because in the Russian legislation there is no federal law on public-private partnership. There are laws on public-private partnership in various regions of Russia. For example, Law of Saratov Region as of April 28, 2010 No. 62-LSR "About Participation of Saratov Region in Public-Private Partnerships".

As a systematic index, the objective function $\mathrm{P}$ was taken, the calculation of this function took into account the differences between modern and ecologicallyoriented development directions.

Modern (economic) approach evaluates the effectiveness of the investment project in terms of economic benefits. It includes two large parts: public and commercial efficiency. This method aims to determine the financial results of the project. It has a goal in its economic nature. Environmental component of this approach is not considered. It is part of the economic flows.

Assessing the impact of the environmental component in the calculation of the objective function $\mathrm{P}$ value allows presenting it in the following way:

$P=P^{*}-C=\left(P^{*}+P e\right)-(T+T e+C m+C o+C e+C i n v-C i n v c o m p) \rightarrow$ MAX 
where

$P \quad$ objective function (profit);

$P^{*}$ profit;

$C$ costs;

$P$ e environmental profit;

$T$ taxes;

$T$ e environmental taxes;

Cm material costs;

Co overhead costs;

Ce environmental costs;

Cinv capital investments;

Cinvcomp capital investment compensation.

Thus, the application of various methods in the evaluation of two investment project variants allows obtaining different values of the objective function.

Table 2. The Initial Data for the Calculation of the Value of the Objective Function (Industrial Company A)

\begin{tabular}{|c|c|c|}
\hline \multirow{3}{*}{ Index } & \multicolumn{2}{|c|}{$\begin{array}{l}\text { The values of the elements of the objective function } \\
\text { (a thousand rubles) }\end{array}$} \\
\hline & economic approach & $\begin{array}{c}\text { ecological-economic approach based } \\
\text { on public-private partnerships }\end{array}$ \\
\hline & 219166.00 & 219166.00 \\
\hline Profit* $(\mathbf{P *})$ & 0.00 & 199.30 \\
\hline Environmental Profit (Pe) & -10001.66 & -10001.66 \\
\hline Taxes $(\mathrm{T})$ & -128031.23 & 13175.75 \\
\hline Environmental taxes (Te) & -205107.85 & -205107.85 \\
\hline The material costs $(\mathrm{Cm})$ & 0.00 & -46.80 \\
\hline The overhead costs (Co) & -25000.00 & -1964.29 \\
\hline Environmental costs $(\mathrm{Ce})$ & -1200.00 & -1200.00 \\
\hline Capital investments (Cinv) & 0.00 & 900.00 \\
\hline $\begin{array}{l}\text { The capital investment } \\
\text { compensation (Cinvcomp) }\end{array}$ & -150174.74 & 15120.45 \\
\hline Total (P): & & \\
\hline
\end{tabular}

All articles in the calculation of costs are negative values. Table 2 shows that the industrial company A can offset part of the costs, taking advantage of the environmental policy.

Various values of the objective function elements, as well as the risks with their distribution among the members of public-private partnership for the second variant of the investment project (risks associated with air pollution, water pollution, soil contamination and soil remediation, damage which may be done to the health of the inhabitants of the region) allow obtaining the following values of indices (the profit $\mathrm{P}$ ) for the effectiveness assessment of the represented project variants. The values of the objective function $\mathrm{P}$ calculated by these methods are -150174.74 and 15120.45 thousand rubles, respectively. 
The environmental component is also taken into account in the calculation of indices. It is expressed in the calculated amount of environmental damage in monetary terms, which is reduced or prevented because of environmental protection measures, and is included in cash flows used for the calculation.

For example, the industrial company A may receive additional income (Environmental Profit) in the amount of 1993 thousand rubles if it sells the waste of industrial activities to specialised institutions.

The positive environmental effect has a specific monetary value. Industrial company A makes additional costs in order to improve its industrial activities (the overhead costs in the amount of 46.8 thousand rubles). Such costs as the search for new suppliers, the conclusion of contracts, conducting experimental work with new materials and the training of new ways of working reflect that the environmental focus changes.

In the implementation of public-private partnership projects, an important condition should be taken into account that not only risks but also the financial burden is distributed among the participants (Recommendations for Implementation of Public Private Partnership in the Russian Federation, 2013). Usually, the involvement of partners is the most powerful state at the initial stage of the project (designing, business plan, the formation of a package of documents). Then, the main burden of the project (including the financial burden) rests with the private partner. The public partner at this stage acts as a "stimulating managers" and provides the second party with different preferences for the practical side of things.

As can be seen from Table 2, economic costs can give subsequently benefit. For example, the industrial company can significantly reduce the taxes (Environmental taxes in Table 2). This is due to the fact that the government provides various incentives (such as accelerated depreciation, investment tax credit, qualified assistance in the design of technical documentation; the state provides guarantees to third parties) to companies that modify their activity and, thus, reduce the negative impact on the environment. Also, the company can receive tax benefits under the federal law. These measures can only be used if a positive environmental effect is confirmed by the fact (reduction of waste, air emissions, wastewater, or improved quality of wastewater treatment).

It should be noted that the second method allows distributing the risks among the project participants according to their competence; it is spreading risk over time (Guidelines for Intercluster Cooperation on the Basis of the Environmental Risk Assessment and Implementation of Green Technologies into the Modern Business Practices, 2013). It has an impact on the value of indicators of the objective function. However, as can be seen from Table 2, in the calculation of the objective function $\mathrm{P}$, an important role in shaping its value is played by elements of an ecological orientation (extra profit from the sale of environmental events, the tax component, as well as reducing the additional costs and environmental costs). These factors make it possible to receive in the second case more favourable results. 


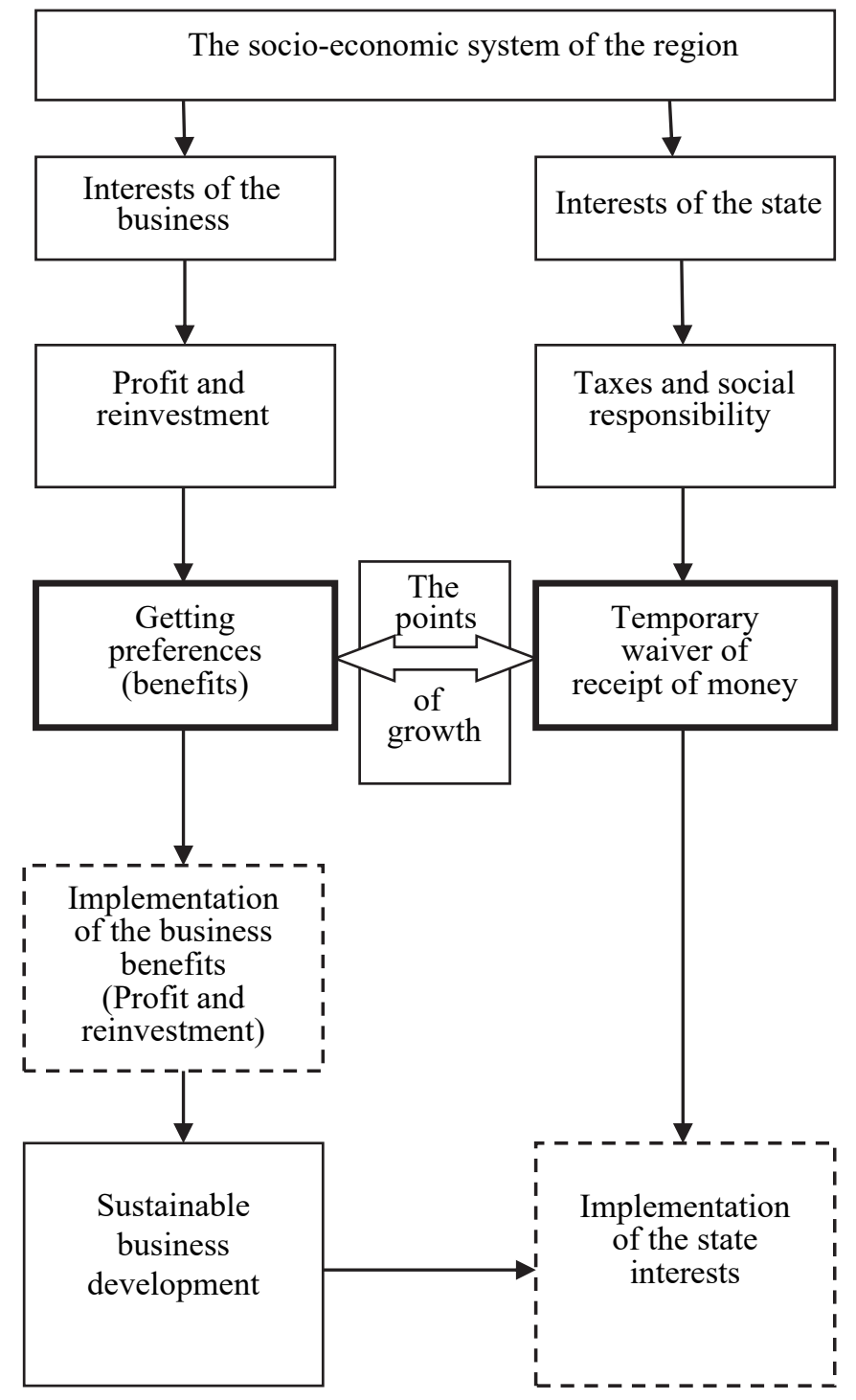

Fig. 2. The mechanism of producing a double effect on the implementation of public-private partnerships.

During this period (when least taxes coming to the budget), it is necessary to clearly define the concept of costs and benefits. It is related to the fact that the public partner pays to the private partner benefits, but itself the benefits are suspended. But this does not mean that it has a loss. State partner applies the principle of sub-optimisation. Government will make a profit in a larger size in the next period of time. Now he gives the private partner the possibility of effective development in a given period of time and the strengthening of the financial situation. It is very important to get a strong development of the economic entity. This is the most advantageous to the state for the strategic development of socio-economic nature. 
For example, tax payments will be lower due to the use of accelerated depreciation methods (applied to fixed assets, equipment based on new technologies). However, this is only part of the tax revenue paid by companies. As seen from Table 2, Taxes (T) and Environmental taxes (Te) make in total 138032.89 thousand rubles in the former case and -3174.09 thousand rubles in the second case. It may look like the government loses money.

However, taking into account the structure of revenue of the regional budget (for Saratov region), you can see the opposite in the systemic consideration.

For example, property company tax is up to $15.2 \%$ in total revenue. Then it can be seen that the corporate income tax and taxes on the total income (profit small and medium-sized businesses, as a rule) make up a total of $33.8 \%$ of revenue in the region (Law of Saratov Region, 2014). It is two times more than the property tax. It should also be noted that $33.8 \%$ of revenue in the region is an income tax on individuals.

It can be concluded that apart from the main part of income received by the regional budget $(67.6 \%)$, there are taxes that may be paid by a successful company and its employees. Thus, the costs that may be at the initial stage of implementation of public-private partnerships have a budget in the region; the next step will bring the government revenue.

According to the scheme above (Fig. 2), the achievement of environmental and economic effects within the framework of the programme of public-private partnerships is possible by shifting phases of the interests of the parties involved and also taking into account aspects such as the time interval, which is associated with the fiscal policy, and the establishment of the optimum ratio "preferencerevenue in the budget" in the given timeslot, as long as the programme is a publicprivate partnership.

Such an approach would have several positive aspects for the development of Saratov region.

Firstly, this corresponds to the strategic goals of the region. These goals are defined in the "Strategy of Socio-Economic Development of Saratov Region in 2025" (Decision of the Government of Saratov Region, 2013) and "State Programme of the Russian Federation "Environmental Protection" for the Period of 2012-2020" (Decision of the Government of the Russian Federation, 2014). The goals include the following: a high level and quality of life, the formation of an efficient economy, attraction of large strategic investors to the region, as well as preserving and improving the natural environment. One of the main problems to be solved in achieving these goals is the reduction of the total anthropogenic load on the environment based on eco-efficiency of the economy.

\section{CONCLUSION}

As can be seen from the calculations above, taking the ecological factor into consideration in the construction of the financial strategy of the enterprise, the development and assessment of investment effectiveness will not only lead to the deterioration of the company economic condition, but will also provide better results. 
The use of this approach is justified in terms of the ecological approach to production management, and is based on economic calculations. The effectiveness of this approach is also proved by the experience of foreign countries, where an environmental management system for many years demonstrating good economic results is used. It should be taken into account that the use of this approach in production could have a good impact on the competitiveness of the regional companies, company advantage as an image-maker, preserving the environment.

\section{REFERENCES}

Guidelines for the assessment of investment projects (2nd edition). (1999). The official publication. Moscow: Economics, 2000 (Approved by: Russian Ministry of Economics, Russian Ministry of Finance, Russian State Committee on Construction, Architecture and Housing Policy. No. BK 477 June 21, 1999).

Evaluation of Public Private Partnership development in Russia. Opinion of Business. Research report. - Moscow: Center of the Public Private Partnership development, 2013.

Recommendations for implementation of Public Private Partnership in the Russian Federation. (2013). Moscow: Center of the Public Private Partnership development.

Guidelines for intercluster cooperation on the basis of the environmental risk assessment and implementation of green technologies into the modern business practices. (2013). The principles of cross-border cooperation of the Leningrad region and the South-East Finland / G. G. Gogoberidze, M. R. Kononenko, Y. A. Lednova, Katja Loven, Pia Anttila, Olli-Pekka Penttinen. St. Petersburg.

Kolotyrin, K. P. (2015). Features of the effectiveness assessment of investments in the field of biological waste / K. P. Kolotyrin, E. N. Eldesbaev, Agricultural Research Magazine, 1, 69-74.

Malakhova, T. N. (2014). The use of modern tools of environmental economics in the field of ecologization of the production sector in Russia / N. I. Kuznetsov, K. P. Kolotyrin, T. N. Malakhova, Scientific Review, 7, 56-60. Retrieved from http://base.garant.ru/12125350/ 1/\#block 1111\#ixzz3kBcR6pYn

Short Statistical Book. Saratov region by Numbers - 2014. (2015). Saratov: The territorial authority of the Federal State Statistics Service of the Saratov region.

Law of the Saratov region of June 30. (2014). No. 85-LSR "On the execution of the regional budget for 2013," Retrieved from http://www.srd.ru/documents/zaks/85-ZSO-30062014.pdf

Decision of the Government of the Saratov region of July 18, 2012. (2013). No. 420-P "On approval of the Strategy of socio-economic development of the Saratov region until 2025 (as amended December 31, 2013)," Saratov.

Decision of the Government of the Russian Federation of April 12, 2014. (2014). No. 326 "On approval of the state program of the Russian Federation "Environmental Protection" on 2012-2020 years," Moscow.

\section{AUTHORS' SHORT BIOGRAPHY}

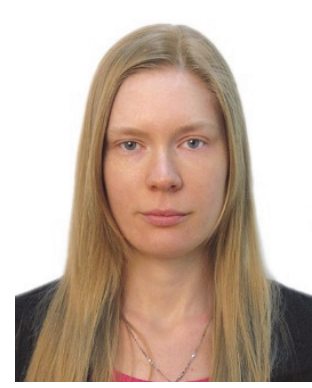

Malakhova Tatiana Nikolaevna is a graduate student of the first year of training in the specialty "Economics and Management of National Economy" (08.00.05). The theme of her Doctoral Thesis is "Organizational-Economic Mechanism of Ecological Sphere of Production on the Basis of Instruments of Public-Private Partnership". She is the author and co-author of several articles. She has participated in several scientific conferences. She also delivered lectures and practical classes to the students. 


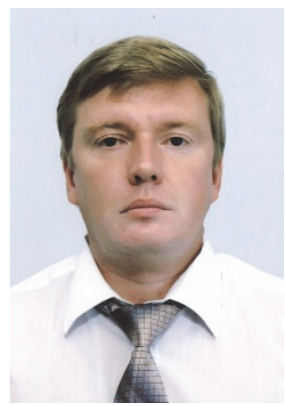

Kolotyrin Konstantin Pavlovich is Doctor of Economics. Now he is an Associate Professor at the Department of Organization of Production and Business Management in the Agricultural Sector.

In 1997, he graduated from Saratov State Technical University with qualification of Engineer-Economist in specialty "Economy and Management in Engineering", specialisation "Organization and Planning of Foreign Economic Activity".

Research interests: environmental economics, project management in the conditions of risk and uncertainty, investment activity. His research results are reflected in more than 100 scientific publications (including 5 monographs), studies consistently reported at national and international conferences. Since 2007, he is a corresponding member of Saratov Regional Branch of the Russian Ecological Academy. Suggestions by K. P. Kolotyrin are included in the "Concept of Waste Production and Consumption in Saratov Region in 2008-2010". The proposed economic calculations are considered in regional programmes "On the Environmental Rehabilitation of Saratov and Balakovo in 2007-2009" and "Environmental Rehabilitation of Saratov Region in 2009-2013".

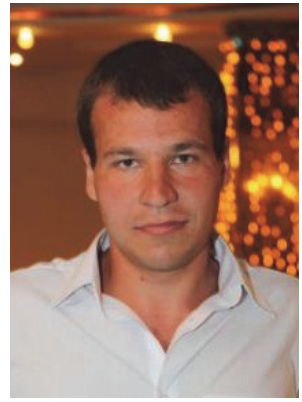

Yakunin Vladimir Aleksandrovich is a Legal Adviser at Saratov State Agrarian University named after Vavilov. From 2005 till 2010 he studied at Saratov State Academy of Law, Department of Theory of State and Law. From 2008 till 2014 he studied at Saratov State Agrarian University named after Vavilov, Department of Management. He received the degree of Master of Science in Management. From 2008 till 2010 he had been working at the Prosecutor's office of Saratov city in position of Public Assistant Prosecutor.

Research interests: political influence on economic processes. 